\title{
The interplay of two invaders: can blooms of the potentially toxic dinoflagellates Prorocentrum cordatum be downregulated by the neritic copepods Acartia tonsa?
}

\author{
Irena V. Telesh ${ }^{1}$, Antonina N. Khanaychenko ${ }^{2}$ and \\ Sergei O. Skarlato ${ }^{3}$ \\ ${ }^{1}$ Zoological Institute, Russian Academy of Sciences, St. Petersburg, Russia \\ ${ }^{2}$ A.O. Kovalevsky Institute of Biology of the Southern Seas, Russian Academy of \\ Sciences, Sevastopol, Russia \\ ${ }^{3}$ Institute of Cytology, Russian Academy of Sciences, St. Petersburg, Russia
}

| Submitted August 4, 2020| Accepted September 3, 2020 |

\begin{abstract}
Summary
The article compares ecological requirements of the potentially toxic bloomforming dinoflagellates Prorocentrum cordatum and their grazers, the neritic calanoid copepods Acartia tonsa in the Baltic and Black seas. A preliminary analysis of the ecological niche characteristics of these two common invasive species allowed assuming the partial juxtaposition of their niches and speculating on the perspectives of this phenomenon for the invasion success and putative top-down control of harmful algal blooms in marine coastal ecosystems.
\end{abstract}

Key words: Acartia tonsa, Baltic Sea, biological invasion, Black Sea, harmful algal blooms, Prorocentrum cordatum

\section{Introduction}

The ecological theory postulates that stable coexistence necessarily involves important ecological differences between species that may serve the background for their niche partitioning (Chesson, 2000). The close congeners, which often share similar environment, are known to be the strongest competitors (Chesson and Kuang, 2008; Telesh et al., 2016). In plankton, trophic relations shape the communities, and interactions between species within one trophic level are usually the most complex (de Jonge, 2007). Moreover, recently it was discovered that the complexity of interactions at different trophic levels in plankton could trigger the chaotic species population dynamics, which occurs even in the most abiotically stable environment and reveals the natural phenomenon coined 'the paradox of chaos' (Telesh et al., 2019). This complexity in pelagic communities increases even more when a non-indigenous species invades the ecosystem. Consequently, the invasion not only enhances biodiversity but also lengthens the trophic chains (in the case of a predatory invertebrate invader) and stimulates interspecific competition (Naumenko and Telesh, 2019).

doi:10.21685/1680-0826-2020-14-3-1 


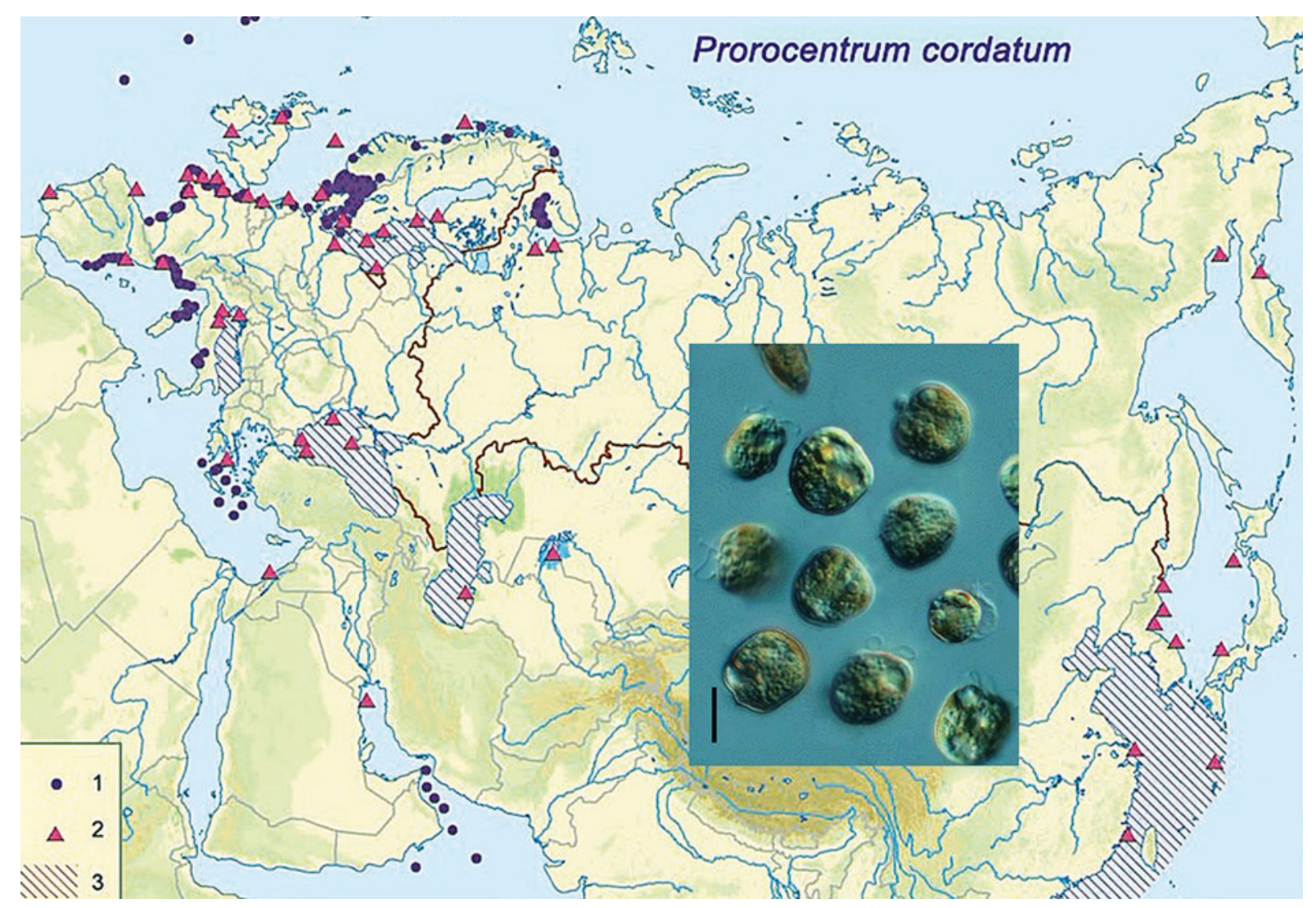

Fig. 1. Distribution of Prorocentrum cordatum in Eurasia: 1 - from GBIF.org (21st October 2018, GBIF Occurrence Download https://doi.org/10.15468/dl.ctsyya ), 2 - according to published data (see text), 3 - in the seas; modified from Khanaychenko et al., 2019. Photo: P. cordatum, live cells in culture, scale bar $10 \mu \mathrm{m}$; photo courtesy of M.A. Berdieva.

Alien species can act as additional stressors that affect both trophic interactions in plankton and the environment in the recipient water body thus modifying the pelagic communities' structure and functions. Meanwhile, successful coexistence of species, irrespective of being native or invasive, requires population of each species to be able to grow in the presence of other species in the community, either competitors or consumers (Chesson, 2000). Therefore, it is possible to hypothesize that species with wider ecological plasticity can demonstrate longer coexistence in a broad range of environmental fluctuations, even when they represent different poles of the predator-prey trophic link or the primary producer-grazer concert. For this reason, it is of special importance to unveil and evaluate the interplay between common and broadly distributed plankton organisms of high ecological and socioeconomic relevance, such as dinoflagellates forming harmful algal blooms (HABs) and their grazers, the neritic copepods that are also preferable food items for the commercial pelagic fish species.
The bloom-forming, potentially toxic mixotrophic dinoflagellate Prorocentrum cordatum (Ostenfeld) J.D. Dodge, 1975 (Alveolata: Dinophyceae: Prorocentrales) is a free-living planktonic species with global distribution in the sea coastal waters (Fig. 1). These dinoflagellates most commonly inhabit marine and brackish waters of the temperate climate zone and in subtropics, less seldom in tropical regions (Heil et al., 2005; Skarlato et al., 2018b, and references therein). Meanwhile, these protists are still expanding their geographic range and invading new marine habitats (Skarlato and Telesh, 2018). For example, $P$. cordatum are native in the Black Sea, but they are non-indigenous in the Baltic Sea, which these dinoflagellates invaded in 1981 (Khanaychenko et al., 2019, and references therein). Vast blooms of $P$. cordatum (red or mahogany tides) in the nearshore sea regions deteriorate water quality and negatively impact the biota in coastal ecosystems since secondary metabolites of these protists cause toxic effects in the environment, aquatic organisms, and humans (Tango et al., 2005; Anderson et al., 


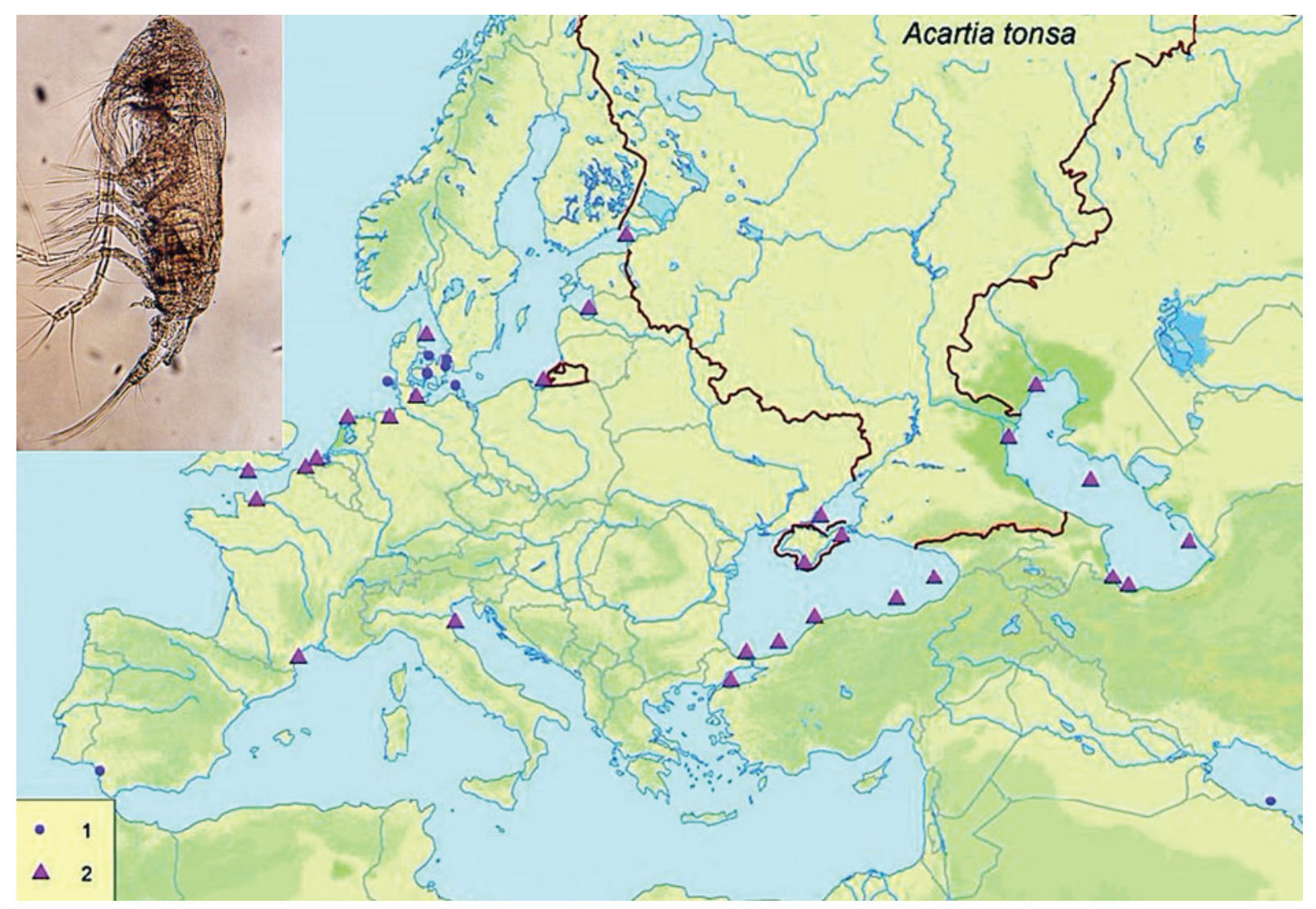

Fig. 2. The invasive part of Acartia tonsa geographic distribution range in Eurasia: 1 - from GBIF.org (12 July 2018; GBIF Occurrence Download https://doi.orgl10.15468/cll.g920iz ), 2 - according to published data (see text); modified from Gubanova and Petrosyan, 2018. Photo: A. tonsa, female, lateral view (from Telesh and Heerkloss, 2004).

2019; Glibert, 2020). As a permanent plankton component of many marine coastal ecosystems, $P$. cordatum is likely exploiting the intricate (and largely underscored so far) interactions in marine pelagic food webs and thus affects the higher trophic levels through the zooplankton grazers (see Figure 2 in Khanaychenko et al., 2019, and references therein).

One of such grazers, the copepod Acartia (Acanthacartia) tonsa Dana, 1849 (Calanoida: Acartiidae), is a common euryhaline planktonic crustacean distributed in temperate and subtropical coastal areas worldwide (Fig. 2). It is a non-indigenous species in the Black Sea (since early 1970-s; Gubanova, 2000) and in the Baltic Sea (since 1925; Rzóska, 1939). Most likely, the species was introduced to both areas with ballast waters of the cargo ships (Brylinski, 1981; Gubanova, 2000; Gubanova and Petrosyan, 2018). In certain coastal regions of the Baltic Sea, A. tonsa sometimes constitutes more than a half of the total zooplankton abundance in late summer, and its population density is increasing from year to year (Polunina, 2018).
These two invaders, a protist and a copepod, are often present in plankton simultaneously and it is possible to assume that their populations can be linked more or less tightly within the marine pelagic food webs. Indeed, researchers often mention the dinoflagellates $P$. cordatum among the food items that can positively affect recruitment and proliferation of the calanoid copepod populations, at least those of the neritic species, and particularly of $A$. tonsa (reviewed by Khanaychenko et al., 2019). However, possible interactions of these species have never been evaluated from the standpoint of their ecological niche dimensions.

Here we compare the ecological requirements of $P$. cordatum and A. tonsa and pose the question whether juxtaposition of their niches exists, and if so, is it a recurring phenomenon. We hypothesize that at the peak population abundances in certain environments, the calanoid copepods $A$. tonsa can downregulate the blooms of the potentially toxic dinoflagellates $P$. cordatum in the sea coastal waters. A preliminary analysis of the ecological niche 
characteristics of these two common invasive species, the protist $P$. cordatum and the copepod $A$. tonsa in the Baltic and Black seas, allowed assuming the partial juxtaposition of their niches and discussing the perspectives of this phenomenon for the invasion success, water quality regulation, and top-down control of HABs in marine coastal waters.

\section{Ecological niches of Acartia tonsa and Pro- rocentrum cordatum in the Baltic Sea}

\section{ACARTIA TONSA}

In the Baltic Sea, A. tonsa was first registered in the coastal waters of the Gdańsk Bay in 1925 at temperatures $>9^{\circ} \mathrm{C}$ and was permanently present in the summer plankton; its abundance used to increase from summer to September; the males were present mainly in August, with juvenile stages most abundant in spring and autumn (Rzóska, 1939). In the SouthEastern Baltic (SEB), where the water temperature has been permanently increasing since the late 1990-s, A. tonsa became a regular component of zooplankton from late spring to late September since the 2000-s, and at present it progressively increases its population density. Specifically, in July 2011, A. tonsa constituted $51 \%$ of the total zooplankton abundance reaching 2.6 ind. $\mathrm{L}^{-1}$ at $17.7^{\circ} \mathrm{C}$ in the littoral zone of SEB down to the $15-\mathrm{m}$ isobath (Polunina, 2018). This finding witnesses for the fact that a self-reproducing population of $A$. tons $a$ exists not only in the western part of the Baltic Sea but, apparently, also in the entire SEB area (Polunina, 2018).

According to the experimental data (Holste and Peck, 2006), the egg production (EP) of the Baltic population of $A$. tonsa was realized in nauplii production within the temperature range from a threshold level of about $12-13{ }^{\circ} \mathrm{C}$ to $28{ }^{\circ} \mathrm{C}$, with the highest hatching rate and mean EP rates (EPR) at $22-23{ }^{\circ} \mathrm{C}$. The lowest EPR (16 eggs ind..$^{-1} \mathrm{~d}^{-1}$ ) was registered at salinities ${ }^{1} 2-5$, in contrast to the highest rate (27 eggs ind. ${ }^{-1} \mathrm{~d}^{-1}$ ) at salinity range $17-$ 25 (Calliari et al., 2006). Therefore, it is likely that salinity restricts reproduction of $A$. tonsa only at

\footnotetext{
${ }^{1}$ Salinity is reported using the Practical Salinity Scale approved by the Joint Panel of Oceanographic Tables and Standards, according to which salinity is defined as a pure ratio, and has no dimensions or units.
}

lowest values (Polunina, 2018), while temperature and food resources restrain further proliferation of A. tonsa population in the vast coastal areas of the Baltic Sea.

\section{PRoRoCENTRUM CORDATUM}

$P$. cordatum is present in plankton perennially worldwide at temperatures $3-31{ }^{\circ} \mathrm{C}$ (Berland and Grzebyk, 1991). In the Baltic Sea, the species was registered in the salinity range of 4.7-17.0, dominating in the phytoplankton community whenever at high (e.g. at salinity 15.7 in the Bay of Mecklenburg) or relatively low salinity (4.8 in the Gulf of Finland) (Heil et al., 2005). Dense populations of these dinoflagellates in the Baltic Sea usually develop from July to October at temperatures above $10{ }^{\circ} \mathrm{C}$ (Hajdu et al., 2005).

The pronounced ecological plasticity of $P$. cordatum is backed up by its high adaptability at the cellular and population levels, including the effective mixotrophic metabolism, pronounced intra-population heterogeneity and variability of cells' responses to environmental stresses (Matantseva et al., 2016; Skarlato et al., 2018a, and references therein). Largely due to those features, $P$. cordatum has successfully conquered the new environments in the Baltic Sea and stepwise suppressed, driven out and replaced the native con-generic species Prorocentrum balticum after nearly two decades of their coexistence (Telesh et al., 2016).

$P$. cordatum is the only one invasive phytoplankton species in the Baltic Sea with the statistically defined ecological niche, which characteristics base on ten environmental parameters measured during the bloom events in 1986-2005 (Table 1). Favorable conditions for the major blooms of $P$. cordatum in the SW Baltic Sea occur at salinity $7.9 \pm 1.8$ and temperature $20.8 \pm 3.7^{\circ} \mathrm{C}$ (Telesh et al., 2016). Since 2000-s, P. cordatum population density has increased significantly in the Southern Baltic Sea (Olenina et al., 2010).

According to the long-term forecasts, the surface temperature of the Baltic Sea is anticipated to increase permanently during the XXI century: up to $2{ }^{\circ} \mathrm{C}$ higher in the Southern, and up to $4{ }^{\circ} \mathrm{C}$ higher in the Northern Baltic (HELCOM, 2013). Thus, one can assume that further increase of the Baltic population of $A$. tonsa might be supported by favorable trophic conditions, likely including the enhanced proliferation of the bloom-forming dinoflagellates $P$. cordatum. 


\section{Major ecological requirements of Acartia tonsa and Prorocentrum cordatum in the Black Sea}

\section{ACARTIA TONSA}

Introduced to the Black Sea in the 1970-s, $A$. tonsa was first found in zooplankton samples in 1976, and since then it has been permanently present in the Black Sea (Gubanova, 2000). In coastal areas (e.g. in the Sevastopol Bay), the abundance peaks of $A$. tonsa are most pronounced in July and August-September (0.2 and 1.2 ind. $\mathrm{L}^{-1}$ in 1976; 0.5 and 3.32 ind. $\mathrm{L}^{-1}$ in 2002, correspondingly) (Gubanova et al., 2002).

Experiments showed that more than $50 \%$ of $A$. tonsa population could survive for 3-7 days after the gradual salinity decrease or increase at a rate of 2-3 $\mathrm{h}^{-1}$ within a range from 3 to 30 . Meanwhile, certain individuals withstood the salinity decrease down to 0.5 and salinity increase up to 70 at a rate of 2-5 day $^{-1}$ (Svetlichny and Hubareva, 2014).

The average Black Sea salinity 18 is close to the optimum for $A$. tonsa and, therefore, its reproduction in the Black Sea is restricted mainly by temperature and availability of food. However, the average annual abundance of $A$. tonsa in the Black Sea is decreasing gradually: it did not exceed $0.5-0.75$ ind. $\mathrm{L}^{-1}$ in 2003-2004, and in 2006-2014, its maximum abundance during the warm season was restricted to 0.1 ind. $\mathrm{L}^{-1}$. The latter effect was supposedly a consequence of introduction and proliferation of the non-indigenous cyclopoid copepod Oithona davisae (Gubanova et al., 2019). At the same time, there are evidences that $A$. tonsa can likewise displace the native copepods. For example, it has outcompeted A. bifilosa in the Mediterranean at the southeastern coast of France (David et al., 2007), impacted negatively the population of $A$. clausi in the Bay of Biscay (Aravena et al., 2009), and substituted the aboriginal Paracartia latisetosa in the Sevastopol Bay, the Black Sea (Gubanova, 2003).

\section{PROROCENTRUM CORDATUM}

The highest concentrations of $P$. cordatum during blooms in the coastal Black Sea waters were registered in 1973-1980; they were progressively decreasing from 1994 to 2005, and during the following years levelled to moderate concentrations not exceeding $13 \times 10^{3}$ cells $\mathrm{mL}^{-1}$ during summer blooms (Khanaychenko et al., 2019, and references therein).

Although to date no direct proof exists for the positive correlation between the decrease in share of
Table 1. Major ecological niche dimensions of Prorocentrum cordatum during the bloom events with the abundances $>1000$ cells $\mathrm{mL}^{-1}$ in the Baltic Sea $(n=17-19)$. Outliers with $>$ 2SD from the mean value were excluded from the analysis. Based on data for the years 19862005 (modified from Telesh et al., 2016).

\begin{tabular}{|c|c|}
\hline Parameter & $\begin{array}{l}\text { Mean value } \\
\quad \pm \text { SD }\end{array}$ \\
\hline Day of the year & $223 \pm 21$ \\
\hline $\begin{array}{l}\text { Water temperature above pycnocline; } \\
\mathrm{T}\left({ }^{\circ} \mathrm{C}\right)\end{array}$ & $20.8 \pm 3.7$ \\
\hline Salinity above pycnocline & $7.9 \pm 1.8$ \\
\hline $\mathrm{PO}_{4}{ }^{3-}\left(\mu \mathrm{mol} \mathrm{L}{ }^{-1}\right)$ & $0.6 \pm 0.7$ \\
\hline Total phosphorus $\left(\mathrm{TP} ; \mu \mathrm{mol} \mathrm{L} \mathrm{L}^{-1}\right)$ & $2.0 \pm 1.4$ \\
\hline Total nitrogen $\left(\mathrm{TN} ; \mu \mathrm{mol} \mathrm{L} \mathrm{L}^{-1}\right)$ & $28.3 \pm 8.7$ \\
\hline $\begin{array}{l}\text { Dissolved inorganic nitrogen } \\
\text { (DIN, calculated; } \mu \mathrm{mol} \mathrm{L}^{-1} \text { ) }\end{array}$ & $1.7 \pm 0.7$ \\
\hline TN/TP ratio & $13.7 \pm 10.3$ \\
\hline $\mathrm{pH}$ & $8.4 \pm 0.2$ \\
\hline $\mathrm{SiO}_{4}^{4-}\left(\mu \mathrm{mol} \mathrm{L}^{-1}\right)$ & $27.1 \pm 14.1$ \\
\hline
\end{tabular}

P. cordatum in the overall phytoplankton abundance and that of $A$. tonsa - in zooplankton of the Black Sea, it is tempting to suggest that temporal match of these two phenomena is a consistent pattern rather than an accidental coincidence.

\section{Outlook}

The preliminary analysis of the available published data revealed that in the Baltic Sea, the populations of both invaders, the protist $P$. cordatum and the copepod $A$. tonsa, are currently increasing in abundance. Meanwhile in the Black Sea, the native P. cordatum has stabilized its population since 2005 , after a significant downward sloping during the previous decades, and the population of $A$. tons continues to decrease gradually (Fig. 3, left panel).

Major environmental parameters required by $P$. cordatum for successful development are concurrent with the favorable conditions for $A$. tonsa recruitment, and the timing of their maximum population development largely coincides (Table 2). Specifically, both species endure a broad range of salinities, between 2 and 37 ( $A$. tonsa - from 0.5 up to 72 in the experiments), and a high variation of temperatures $\left(9-28^{\circ} \mathrm{C}\right)$. The optimum range of water temperature for the population development of $A$. tonsa (15-28 ${ }^{\circ} \mathrm{C}$ ) is slightly wider than that for $P$. cordatum $\left(17-25^{\circ} \mathrm{C}\right)$. However, the optimum salinities for the population development of $A$. tonsa (15-22) 

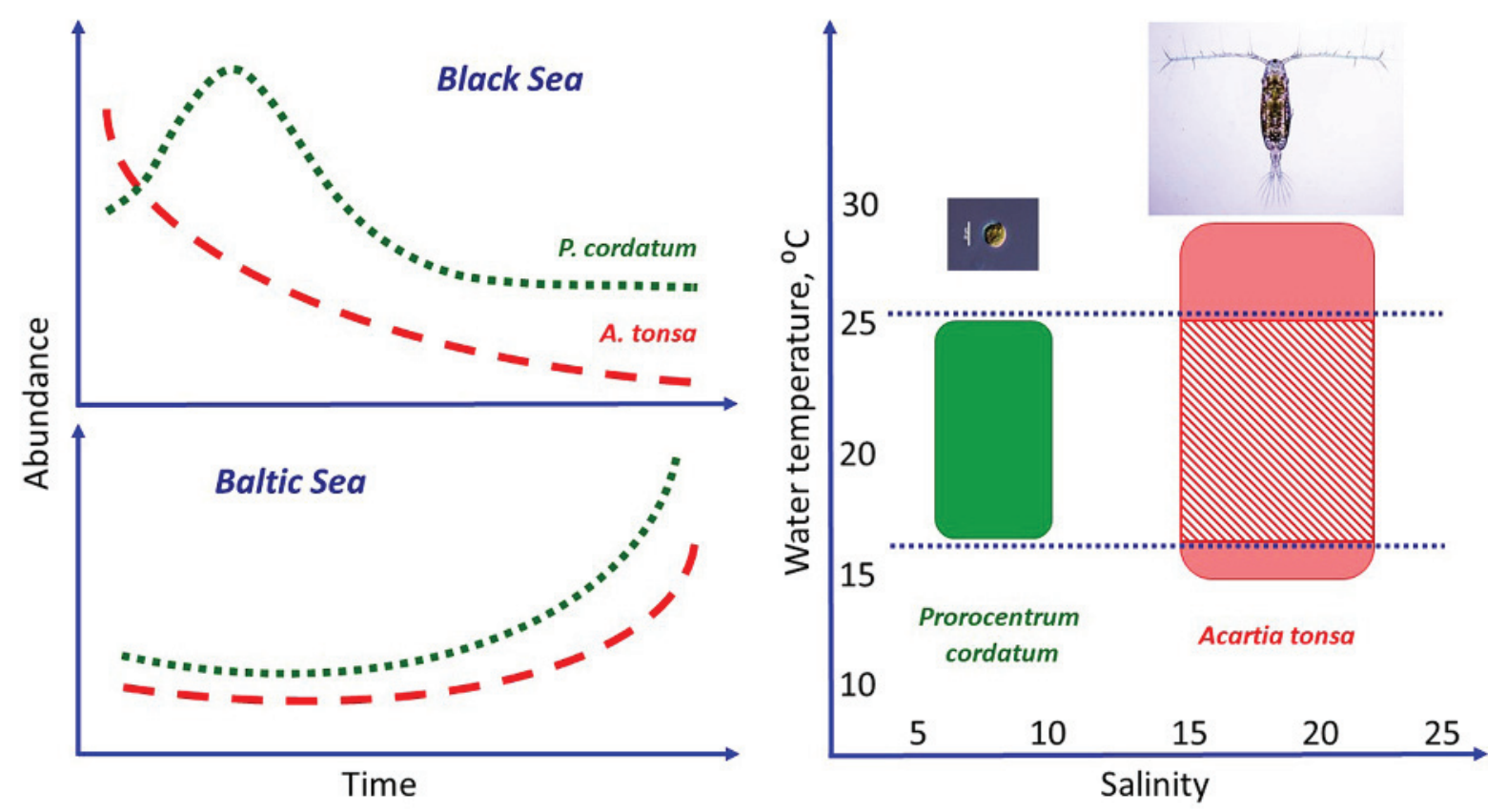

Fig. 3. Conceptual model of water temperature/salinity preference (right panel) and long-term population dynamics of the bloom-forming dinoflagellates Prorocentrum cordatum (thick dotted line) and the calanoid copepods Acartia tonsa (dashed line; left panel) in the Baltic and Black seas. Type of P. cordatum dynamics in the Black Sea highlights the fact that it is a native species here. The thin dotted lines and the diagonally striped area in the water temperature/salinity 'niche' of $A$. tonsa (right panel) indicate the range of water temperature values, which overlap with the relevant characteristics for $P$. cordatum. Photos: $P$. cordatum, scale bar $20 \mu \mathrm{m}$, from open sources; $A$. tonsa, photo courtesy of L.S. Svetlichny.

and P. cordatum (6-10) differ substantially (Fig. 3, right panel).

These results allow concluding that at present, the major ecological requirements of $P$. cordatum and $A$. tons $a$ in the Baltic and Black sea coastal waters juxtapose only partially. In particular, both species are present in plankton during May-November, reach maximum population abundances usually in August, and their preferable temperature conditions largely coincide. However, the salinity preferences of $P$. cordatum and $A$. tons a do not overlap; moreover, they are completely different, thus indicating that these species inhabit the disjoint ecological niches. Therefore, currently the presumable downregulation of the blooms of the potentially toxic dinoflagellates $P$. cordatum by the neritic copepods $A$. tonsa is unlikely.

Meanwhile, with the on-going eutrophication and global warming the populations of $A$. tonsa can proliferate in the near future, also in the Black Sea, and react positively to the possible shifts in phytoplankton community structure and dynamics, particularly to those caused by the enhancing water temperature and/or decreasing salinity. The related shifts in the dominant microalgae in favor of the bloom-forming species and the projected enhanced magnitude of HABs could likewise affect their grazers and cause the overall plankton community restructuring both in the Black and Baltic seas.

Thus, further in-depth research of the ecological niche juxtaposition of the invasive bloom-forming dinoflagellates $P$. cordatum and the common neritic calanoid copepods $A$. tonsa is needed for the adequate interpretation of the ongoing changes in the coastal sea plankton communities following eutrophication and the related ecosystem processes. This new knowledge will facilitate forecast of the harmful effects of the potentially toxic bloomforming protists on the higher trophic levels, including commercial fish populations, and top-down regulation of harmful algal blooms through the effective grazing of $\mathrm{HAB}$-species by the calanoid copepods. 
Table 2. Major ecological niche characteristics of Prorocentrum cordatum ${ }^{1}$ and Acartia tonsa ${ }^{2}$ in the Baltic and Black seas and in the experiments.

\begin{tabular}{|c|c|c|}
\hline Parameter & $\begin{array}{l}\text { Prorocentrum } \\
\text { cordatum }\end{array}$ & $\begin{array}{c}\text { Acartia } \\
\text { tonsa }\end{array}$ \\
\hline $\begin{array}{l}\text { Present in plankton } \\
\text { Maximum abundance }\end{array}$ & $\begin{array}{l}\text { Year-round } \\
\text { August }\end{array}$ & $\begin{array}{l}\text { May-November } \\
\text { August }\end{array}$ \\
\hline $\begin{array}{l}\text { Water temperature, } \mathrm{T}\left({ }^{\circ} \mathrm{C}\right) \text { : } \\
\text { - Minimum (survival in } \\
\text { nature) } \\
\text { - Minimum ( } A \text {. tonsa dor- } \\
\text { mant eggs hatch) } \\
\text { - Optimum (for popula- } \\
\text { tion development) } \\
\text { - Maximum (survival) }\end{array}$ & $\begin{array}{c}3 \\
- \\
17-25 \\
31\end{array}$ & $\begin{array}{c}9 \\
\geq 10 \\
15-28 \\
-\end{array}$ \\
\hline $\begin{array}{l}\text { Salinity: } \\
\text { - Minimum (survival) } \\
\text { - Minimum (A. tonsa egg } \\
\text { production) } \\
\text { - Optimum (for popula- } \\
\text { tion development) } \\
\text { - Maximum (survival) }\end{array}$ & $\begin{array}{c}2\left(0.5^{*}\right) \\
- \\
6-10 \\
37\end{array}$ & $\begin{array}{c}<1^{*} \\
2-5^{*} \\
15-22 * \\
70 *\end{array}$ \\
\hline
\end{tabular}

${ }^{1}$ Based on data from: Berland and Grzebyk, 1991; Olenina et al., 2016; Telesh et al., 2016 (and references therein). 2 Based on data from: Sullivan and McManus, 1986; Marcus and Lutz, 1994; Khanaychenko, 1989; Cervetto, 1999; Calliari et al., 2006; Svetlichny and Hubareva, 2014; Gubanova and Petrosyan, 2018.

- Not relevant or no data.

* In experiments.

\section{Acknowledgements}

The research was funded in parts by the Russian Science Foundation (project 19-14-00109; I.T., S.S; the analysis of ecological prerequisites of $P$. cordatum proliferation in the marine coastal waters); Russian Foundation for Basic Research (project 19-04-00217; I.T.; analysis of dynamics of abiotic parameters and biotic interactions in plankton); the Research Program No AAAA-A19-119020690091-0 at the Zoological Institute RAS (I.T.; analyses of long-term protistan diversity in the Baltic coastal waters); the Budgetary Program No 01242019-0005 at the Institute of Cytology RAS (S.S.; dinoflagellates database analyses), and the Russian Academy of Sciences grant agreement AAAA-A18-118021350003-6 at the IBSS RAS (A.K.; analyses of the copepod dynamics in the Black Sea).

\section{References}

Anderson C.R., Berdalet E., Kudela R.M., Cusak C.K., Silke J., O’Rourke E. et al. 2019. Scaling up from regional case studies to a global Harmful Algal Bloom observing system. Frontiers in Marine Science. 6, 250.
Aravena G., Villate F., Uriarte I., Iriarte A. and Ibáñez B. 2009. Response of Acartia populations to environmental variability and effects of invasive congenerics in the estuary of Bilbao, Bay of Biscay. Estuarine, Coastal and Shelf Science. 83, 621-628.

Berland B. and Grzebyk D. 1991. Prorocentrum minimum (Dinophycées). In: Sournia A. et al. (Eds.). Le phytoplankton nuisible des côtes de France. Institut francais de recherché pour l'exploitation de la mer. Brest, France, pp. 101-113.

Brylinski J.M. 1981. Report on the presence of Acartia tonsa Dana (Copepoda) in the harbour of Dunkirk (France) and its geographical distribution in Europe. Journal of Plankton Research. 3 (2), 255-260.

Calliari D., Andersen C.M, Thor P., Gorokhova E. and Tiselius P. 2006. Salinity modulates the energy balance and reproductive success of cooccurring copepods Acartia tonsa and A. clausi in different ways. Marine Ecology Progress Series. 312, 177-188.

Cervetto G., Gaudy R. and Pagano M. 1999. Influence of salinity on the distribution of Acartia tonsa (Copepoda, Calanoida). Journal of Experimental Marine Biology and Ecology. 239, 33-45.

Chesson P. 2000. Mechanisms of maintenance of species diversity. Annual Review of Ecology and Systematics. 31, 343-366.

Chesson P. and Kuang J. 2008. The interaction between predation and competition. Nature. 456, 235-238.

David V., Sautour B. and Chardy P. 2007. Successful colonization of the calanoid copepod Acartia tonsa in the oligomesohaline area of the Gironde estuary (SW France) - Natural or anthropogenic forcing? Estuarine, Coastal and Shelf Science. 71, 429-442.

de Jonge V.N. 2007. Toward the application of ecological concepts in EU coastal water management. Marine Pollution Bulletin. 55, 407-414.

Glibert P.M. 2020. Harmful algae at the complex nexus of eutrophication and climate change. Harmful Algae. 91, 101583.

Gubanova A. 2000. Occurrence of Acartia tonsa Dana in the Black Sea. Was it introduced from the Mediterranean? Mediterranean Marine Science. 1 (1), 105-109.

Gubanova A.D. 2003. Long-term changes in the specific composition and abundance of copepods Acartia Dana genera in the Sevastopol Bay. In: Modern state of biodiversity in the coastal waters of Crimea (Black Sea sector). (Eremeev V.N., Gayevskaya A.V., Eds). Sevastopol. EKOSIGidrophizika, 94-103 (in Russian). 
Gubanova A.D., Garbazey O.A., Popova E.V., Altukhov D.A. and Mukhanov V.S. 2019. Oithona davisae: naturalization in the Black Sea, interannual and seasonal dynamics, and effect on the structure of the planktonic copepod community. Oceanology. 59 (6), 912-919.

Gubanova A.D. and Petrosyan V.G. 2018. Acartia tonsa Dana, 1849. In: Dgebuadze Yu.Yu., Petrosyan V.G. and Khlyap L.A. (Eds.). The most dangerous invasive species of Russia (TOP-100). M.: KMK Scientific Press, pp. 363-368 (in Russian).

Gubanova A.D., Polikarpov I.G., Saburova M.A. and Prusova I. 2002. Long-term dynamics of mesozooplankton by the example of the copepoda community in Sevastopol Bay (1976-1996). Oceanology. 42, 512- 520 .

Hajdu S., Pertola S. and Kuosa H. 2005. Prorocentrum minimum (Dinophyceae) in the Baltic Sea: morphology, occurrence - a review. Harmful Algae. 4 (3), 471-480.

Heil C.A., Glibert P.M. and Fan C. 2005. Prorocentrum minimum (Pavillard) Schiller: a review of a harmful algal bloom species of growing worldwide importance. Harmful Algae. 4 (3), 449470.

HELCOM, 2013. Climate change in the Baltic Sea Area: HELCOM thematic assessment in 2013. Baltic Sea Environment Proceedings. No. 137.

Khanaychenko A.N., Telesh I.V. and Skarlato S.O. 2019. Bloom-forming potentially toxic dinoflagellates Prorocentrum cordatum in marine plankton food webs. Protistology. 13 (3), 95-125.

Khanaychenko A.N. 1989. Mass cultivation of copepods in semi-continuous system. Proc. IV AllUnion Science and Technology conference, Sevastopol, URSS. 66-67 (in Russian).

Marcus N.H. and Lutz R.V. 1994. Effects of anoxia on the viability of subitaneous eggs of planktonic copepods. Marine Biology. 121, 83-87.

Matantseva O., Skarlato S., Vogts A., Pozdnyakov I., Liskow I., Schubert H. and Voss M. 2016. Superposition of individual activities: urea-mediated suppression of nitrate uptake in the dinoflagellate Prorocentrum minimum revealed at the population and single-cell levels. Frontiers in Microbiology. 7,1310 .

Naumenko E.N. and Telesh I.V. 2019. Impact of the invasive species Cercopagis pengoi (Ostroumov, 1891) on the structural and functional organization of zooplankton in the Vistula Lagoon of the Baltic Sea. Russian Journal of Biological Invasions. 10 (3), 246-257.

Olenina I., Wasmund N., Hajdu S., Jurgensone I., Gromisz S. et al. 2010. Assessing impacts of invasive phytoplankton: the Baltic Sea case. Marine Pollution Bulletin. 60, 1691-1700.

Polunina Ju.Ju. 2018. Reproductive strategies of non-native planktonic crustaceans in the southeastern Baltic Sea. Russian Journal of Biological Invasions. 9 (1), 75-82.

Rzóska Ju. 1939. Materiały do znajomości plamktonu Małego morza: Copepoda. Arch. Hydrobiol. Ryb. 12 (1-2), 55-87.

Skarlato S.O. and Telesh I.V. 2018. Prorocentrum minimum - Dinoflagellates. In: Dgebuadze Yu.Yu., Petrosyan V.G. and Khlyap L.A. (Eds.), The most dangerous invasive species of Russia (TOP-100). M.: KMK Scientific Press, pp. 227-233 (in Russian).

Skarlato S., Filatova N., Knyazev N., Berdieva M. and Telesh I. 2018a. Salinity stress response of the invasive dinoflagellate Prorocentrum minimum. Estuarine, Coastal and Shelf Science. 211, 199-207.

Skarlato S.O., Telesh I.V., Matantseva O.V., Pozdnyakov I.A., Berdieva M.A., Schubert H., Filatova N.A., Knyazev N.A. and Pechkovskaya S.A. 2018b. Studies of bloom-forming dinoflagellates Prorocentrum minimum in fluctuating environment: contribution to aquatic ecology, cell biology and invasion theory. Protistology. 12 (3), 113-157.

Sullivan B.K. and McManus L.T. 1986. Factors controlling seasonal succession of the copepods Acartia hudsonica and A. tonsa in Narragansett Bay, Rhode Island: temperature and resting egg production. Marine Ecology Progress Series. 28, 121-128.

Svetlichny L. and Hubareva E. 2014. Salinity tolerance of alien copepods Acartia tonsa and Oithona davisae in the Black Sea. Journal of Experimental Marine Biology and Ecology. 461, 201-208.

Tango P.J., Magnien R., Butler W., Luckett C., Luckenbach M., Lacouture R. and Poukish C. 2005. Impacts and potential effects due to Prorocentrum minimum blooms in Chesapeake Bay. Harmful Algae. 4 (3), 525-531.

Telesh I.V. and Heerkloss R. 2004. Atlas of Estuarine Zooplankton of the Southern and Eastern Baltic Sea. Part II: Crustacea. Verlag Dr. Kovač, Hamburg.

Telesh I.V., Schubert H. and Skarlato S.O. 2016. Ecological niche partitioning of the invasive dinoflagellate Prorocentrum minimum and its native congeners in the Baltic Sea. Harmful Algae. 59, $100-111$.

Telesh I.V., Schubert H., Joehnk K.D., Heerkloss R., Schumann R., Feike M., Schoor A. and Skarlato S.O. 2019. Chaos theory discloses triggers and drivers of plankton dynamics in stable environment. Scientific Reports. 9, 20351. 
Address for correspondence: Irena V. Telesh. Zoological Institute RAS, Universitetskaya Emb. 1, 199034 St. Petersburg, Russia; e-mail: Irena.Telesh@zin.ru 